\title{
Characterization and spatio-temporal dynamics of Cylindrospermopsis raciborskii in an Amazonian Lagoon, Ecuador
}

\section{(Caracterización y dinámica espacio-temporal de Cylindrospermopsis raciborskii en una laguna amazónica, Ecuador)}

\author{
Judith Venegas ${ }^{1}$, Pablo Castillejo Pons ${ }^{2}$, Susana Chamorro Arias ${ }^{2}$, Ivonne Carrillo \\ Paredes $^{2}$, Eduardo Lobo Alcayaga ${ }^{3}$
}

\begin{abstract}
:
The cyanobacteria Cylindrospermopsis raciborskii, is a fresh water ubiquitous species from tropical to temperate weather. It is potentially capable of producing toxins. Thus it is necessary to monitor its presence in fresh waters associated to recreational use activities and human consumption. There are official reports and one thesis reporting the presence of $C$. raciborskii in Ecuador. Nevertheless, this country does not appear in the latest distribution maps of this species in the scientific literature. In this article, we report the presence of $C$. raciborskii in Ecuador, together with the characterization of the environmental conditions of one of the habitats where this species is present: the Limoncocha lagoon, province of Sucumbíos.
\end{abstract}

Keywords: Amazon; cyanobacteria; South America; Limoncocha.

\section{Resumen:}

La cianobacteria Cylindrospermopsis raciborskii es una especie omnipresente en agua dulce desde el clima tropical hasta el clima templado. Es potencialmente capaz de producir toxinas. Por lo tanto, es necesario monitorear su presencia en aguas dulces asociadas a actividades de uso recreativo y consumo humano. Hay informes oficiales y una tesis que informan la presencia de $C$. raciborskii en Ecuador. Sin embargo, este país no aparece en los últimos mapas de distribución de esta especie en la literatura científica. En este artículo, reportamos la presencia de $C$. raciborskii en Ecuador, junto con la caracterización de las condiciones ambientales de uno de los hábitats donde esta especie está presente: la laguna Limoncocha, provincia de Sucumbíos.

Palabras clave: Amazonas, cianobacteria, Sudamérica, Limoncocha.

\section{Introduction}

Cyanobacteria are photosynthetic prokaryotic organisms present in fresh water ecosystems. Some of the species are highly tolerant to extreme conditions as thermal springs over $60^{\circ} \mathrm{C}$, hypersaline lakes, or polar regions (Bonilla et al., 2012). Cyanobacteria can grow sharply under certain environmental conditions, phenomenon called bloom (Smayda, 1997). Some of them are able to produce toxins that confer a competitive advantage against other groups. This is the case of Cylindrospermopsis raciborskii (Woloszynska, 1912), a filamentous cyanobacteria (order Nostocales) able to fix nitrogen and to form akinetes, a thick-walled dormant cell that serves as a survival structure. Thus

\footnotetext{
1 Centro de Información y Asesoramiento Toxicológico (CIATOX), Quito, Ecuador (judyvenegas@gmail.com).

2 Universidad Internacional SEK, Quito, Ecuador ( \{pablo.castillejo, susana.chamorro, emma.carrillo\} @uisek.edu.ec).

${ }^{3}$ Universidade de Santa Cruz do Sul, Santa Cruz do Sul, Brasil (lobo@unisc.br).
} 
its presence in Ecuador might be a potential environmental and public health hazard (Stüken et al., 2006).

Usually, the Asiatic and Australian C. raciborskii strains are capable of producing the toxin cylindrospermopsina, while the South American synthesizes PSP (Paralytic Shellfish Poison). Nevertheless, European, African and North American strains have not shown any toxin production so far (Stüken et al., 2006).

The first report about C. racibosrskii toxicity was in 1985, from a strain isolated in a water reservoir for human consumption in Australia (Hawkins et al., 1985). In 1996, in Caruaru, Brazil, 52 people died due to a $C$. raciborskii bloom in another water reservoir for human consumption (Azevedo et al., 2002).

C. raciborsskii has been described for the first time in Java Island, Indonesia in 1912. Since then, it has been reported in plenty of tropical locations until 1937, when Skuja (1937) reported it in Europe for the first time. Nowadays, C. raciborskii is found in both hemispheres, in rivers, lakes, reservoirs being a cosmopolite species (Antunes et al., 2015). The increasing presence in temperate climates began to draw the attention of the scientific community (Padisák, 1997; Antunes et al., 2015).

In Ecuador, $C$. raciborskii has been reported in Daule-Peripa reservoir and Daule river (Provincia de Guayas) in 2011 (Prado M. \& Bucheli R., 2012) and Yaguacocha lagoon (Provincia de Imbabura) by Saelens (2015). Nevertheless, these findings have not been reported in the scientific literature, thus Ecuador has been excluded from the latest report on C. raciborskii geographical distribution proposed by Antunes in 2015.

We report the first record of $C$. raciborskii in the Ecuadorian Amazon region, and describe its hosting habitat: the Limoncocha Lagoon. In addition, this work aims to update the worldwide presence of $\mathrm{C}$. raciborskii, adding Ecuador to the distribution area compiled by Antunes (2015).

\section{Material and Methods}

\subsection{Study area and field sampling}

Limoncocha lagoon belongs to the Amazonas river basin. It is located in Shushufindi County (called Canton), in the Limoncocha Biological Reserve (long -76,600000; lat 0,$400000 ; 244 \mathrm{~m}$ ) (Figure 1). This wetland, designed as a RAMSAR site since 1998 (Mae, 2016), contains both lentic and lotic ecosystems, whose central axis is the Limoncocha lagoon.

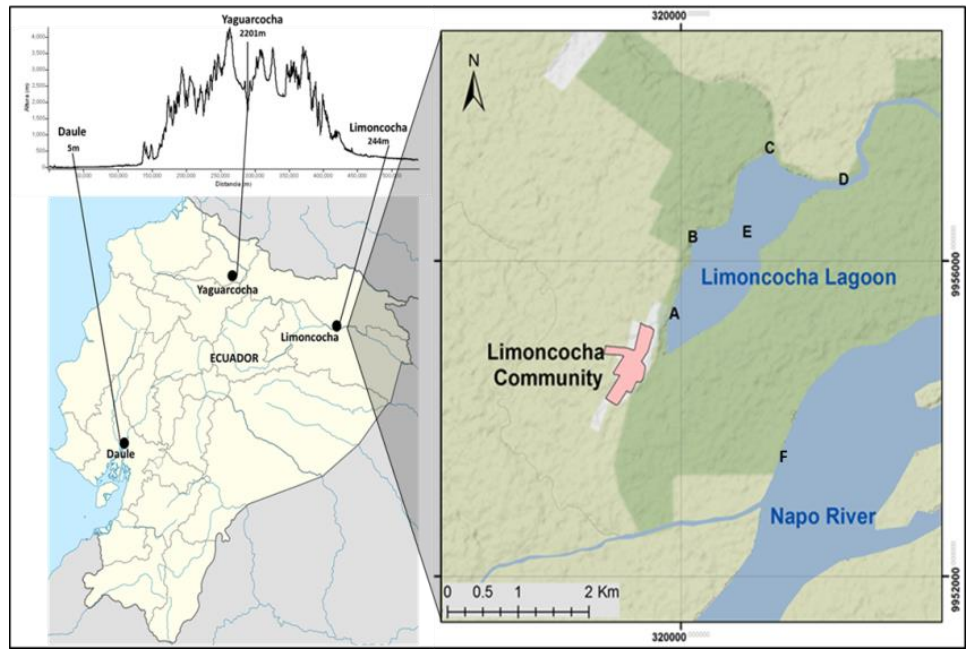

Figure 1. Places in Ecuador where C. raciborskii has been found and water sampling spots at Limoncocha lagoon: A: Embarcadero; B: Playayacu; C: Pishira river; D; Caño; E: Deep Zone. F: Napo River. Instituto Geográfico Militar, 2017. 


\subsection{Water Sampling}

The locations for sampling were randomly picked. Two sampling points were selected at the confluence of two creeks called Pishira River and Playayacu River, which present sewage water running off from the village Parroquia de Limoncocha (follow Limoncocha village). The other three sites were selected randomly: Caño, Embarcadero (close to the lagoon shore) and Deep Zone (in the center of the lagoon) (Figure 1). Samples were collected in $250 \mathrm{~mL}$ plastic bottles (Vand Dorn Eijkelkamp (C) and stored at $4^{\circ} \mathrm{C}$ for later analysis.

\subsection{Physichochemical parameters}

Temperature, $\mathrm{pH}$, dissolved oxygen and conductivity were measured in situ with Multiparameter $\mathrm{HACH}$ ( $)$. Phosphate and nitrate anions, ammonia, ODB5, were determined with $\mathrm{HACH}$ method (Hach, 2000) using ascorbic acid 8048, HACH 4000 spectrophotometer with a $890 \mathrm{~nm}$ wave length. The ammonia was determined HACH 8038 colorimetric method, $\mathrm{HACH} 400$ spectrophotometer with a length wave of $425 \mathrm{~nm}$.

\subsection{Cyanobacteria species identification}

The collected specimens were identified based on taxonomic analyses (Komárek \& Komártková-Legnerova, 2003) under the optic microscope (Olympus cx31), 100x. Photographs were taken using "Applied vision 4" camera system (Ken-a-vision, n.d.).

\subsection{Data analysis}

Correlation between temperature and density of $C$. raciborskii was established by using the Pearson coefficient of correlation " $r$ " with $\alpha=0.05$. Prior to the analysis, the biological data was base-e Log transformed. The analyses were performed using PAST software (Hammer et al., 2001).

\section{Results and discussion}

\subsection{Temperature, $\mathrm{pH}$, salinity, ammonia nitrogen and phosphorus dynamics in Limoncocha lagoon}

Limoncocha lagoon is highly eutrophicated due to natural processes and sewage from nearby Limoncocha village (Durañona, 2005). Its location (Fig.1) determines a tropical rainy climate with a daily average temperature of $28^{\circ} \mathrm{C}$. The lagoon temperature ranges from $17^{\circ} \mathrm{C}$ close to Pishira River affluent mouth to $32,3^{\circ} \mathrm{C}$ from the warmest areas of the surface water in the middle of the lagoon. The $\mathrm{pH}$ range ranges from 6 to 9, very suitable values for C. raciborskii growth (Briand et al., 2002; Padisák, 1997; Padisák \& Reynolds, 1998).

The salinity is low as conductivity ranges up to $180 \mu \mathrm{S} / \mathrm{cm}$, are congruent with those for freshwater values (salt content below 2000ppm) (Llamas \& Custodio, 1976).

Ammonia levels contributed to the total inorganic nitrogen detected since nitrates and nitrites were out of our detection threshold. The concentration of ammonia varied from 0,46 to $0,56 \mathrm{mg} / \mathrm{L}$ consistent with the values for a eutrophic lake (Table 1).

Dissolved phosphorus ranged from $0,2 \mathrm{mg} / \mathrm{L}$ at the deep zone to $1.6 \mu \mathrm{g} / \mathrm{L}$ at mouth of Playayacu River, congruent with the values for a eutrophic lake. 
Table 1. Physic-chemical parameters at sample stations in September $(\mathrm{S})$ and November (N): Temperature $(\mathrm{T}), \mathrm{pH}$, conductivity $(\mathrm{C})$, nitrates $\left(\mathrm{NO}_{3}{ }^{-}\right)$, ammonia $\left(\mathrm{NH}_{4}{ }^{+}\right)$, orthophosphate $\left(\mathrm{PO}_{4}{ }^{3-}\right)$, and biological oxygen demand $\left(\mathrm{ODB}_{5}\right)$.

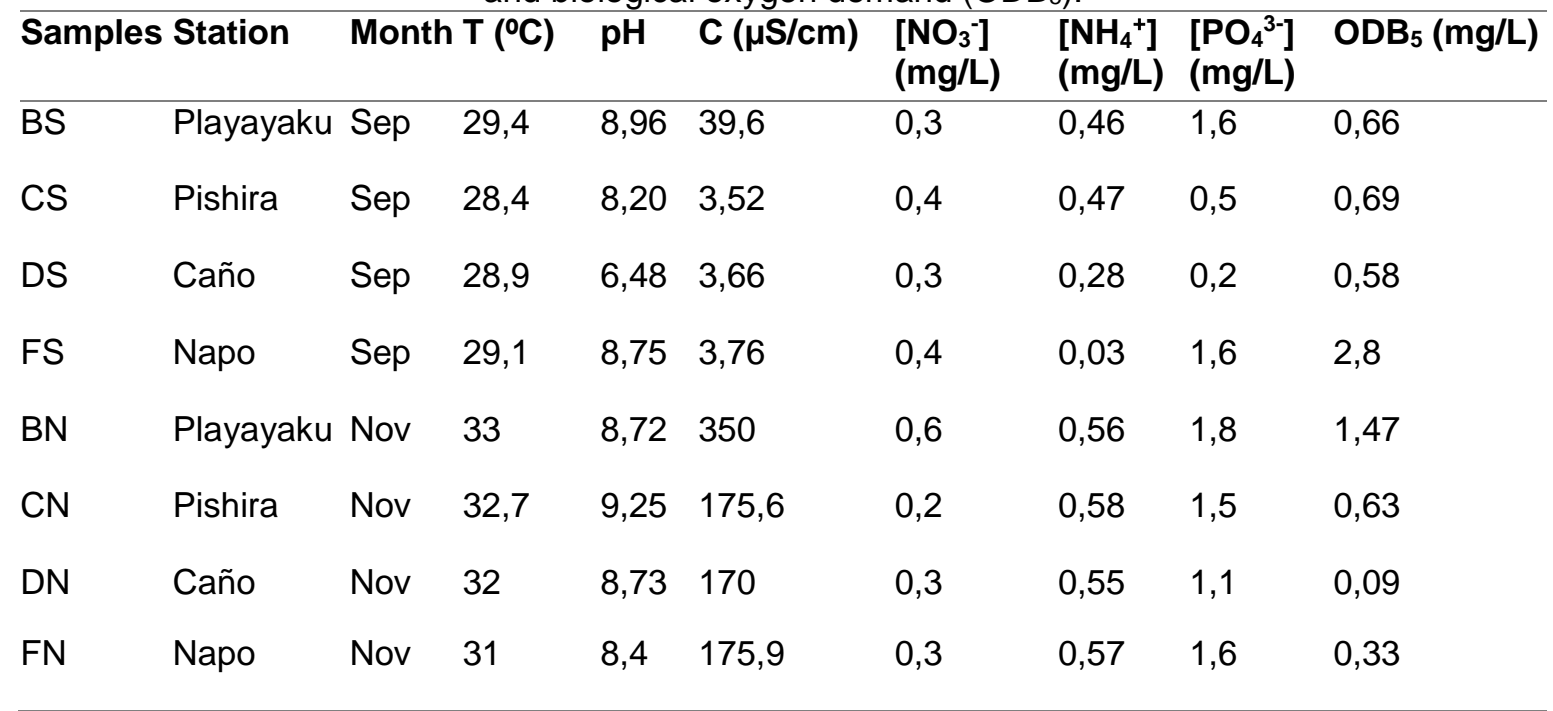

\subsection{C. raciborskii at Limoncocha lagoon:}

The thricomes collected were $30 \mu \mathrm{m}$ up to $70 \mu \mathrm{m}$ long, no circular morpho types were found. Only a 23 per cent of the samples observed contained two heterocysts per thricome being the majority the single heterocyst thricome (Figure 2.a). These structures are specialized nitrogen-fixing cells formed during nitrogen starvation (Berman-Frank et al., 2003).
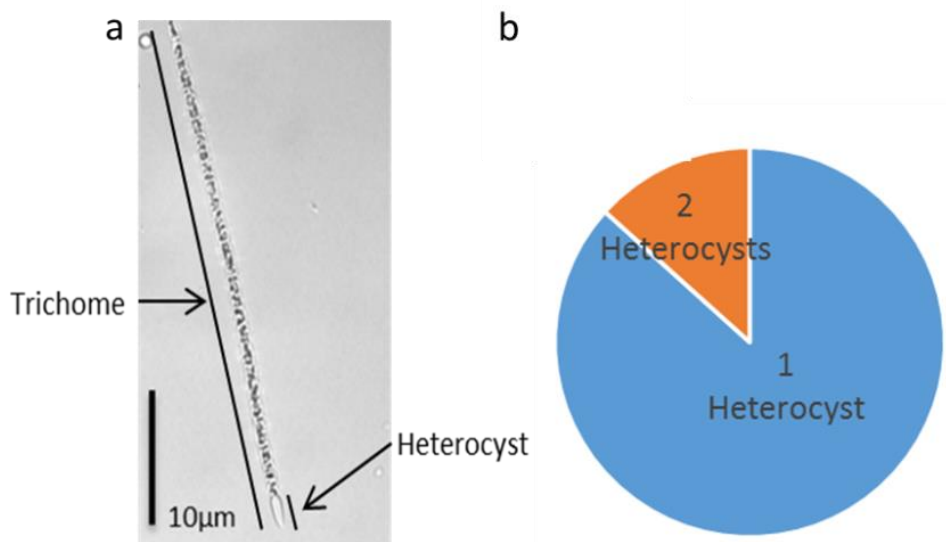

Figure 2. C. raciborskii thricome from Limoncocha lagoon under optical microscope (100x). b: percentage of thricomes with one and two heterocysts.

\subsection{C. raciborskii potential blooms in Limoncocha lagoon.}

Temperature, $\mathrm{pH}$ and salinity data observed in the lagoon are suitable for $C$. raciborskii growth throughout the year. Furthemore, there is a strong correlation (Figure 3) between increase of temperature and density of $C$. raciborskii thricomes at the lagoon $(r=$ 0,$85 ; p<0.05$ ) (Figure 3). Eutrophication decrease the light intensity into the water, thus Secchi deep reaches just $30 \mathrm{~cm}$ from the water surface (Figure 4). This confers an adaptive advantage to the shade-tolerant phytoplancton (Schwaderer et al., 2011) as C. raciborskii (Briand et al., 2002). 


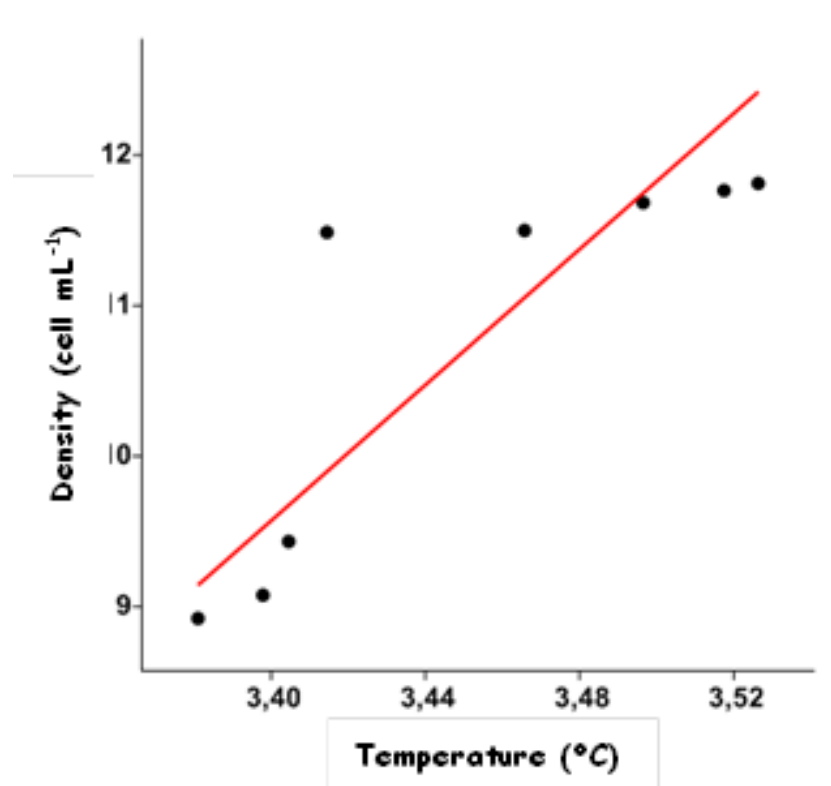

Figure 3. Temperature $\left({ }^{\circ} \mathrm{C}\right)$ versus density of $C$. raciborskii (cell $\left.\mathrm{mL}-1\right)$. Data were $\mathrm{LN}(\mathrm{X}+1)$ transformed. Coefficient of Correlation, $r=0,85(p<0.05)$.
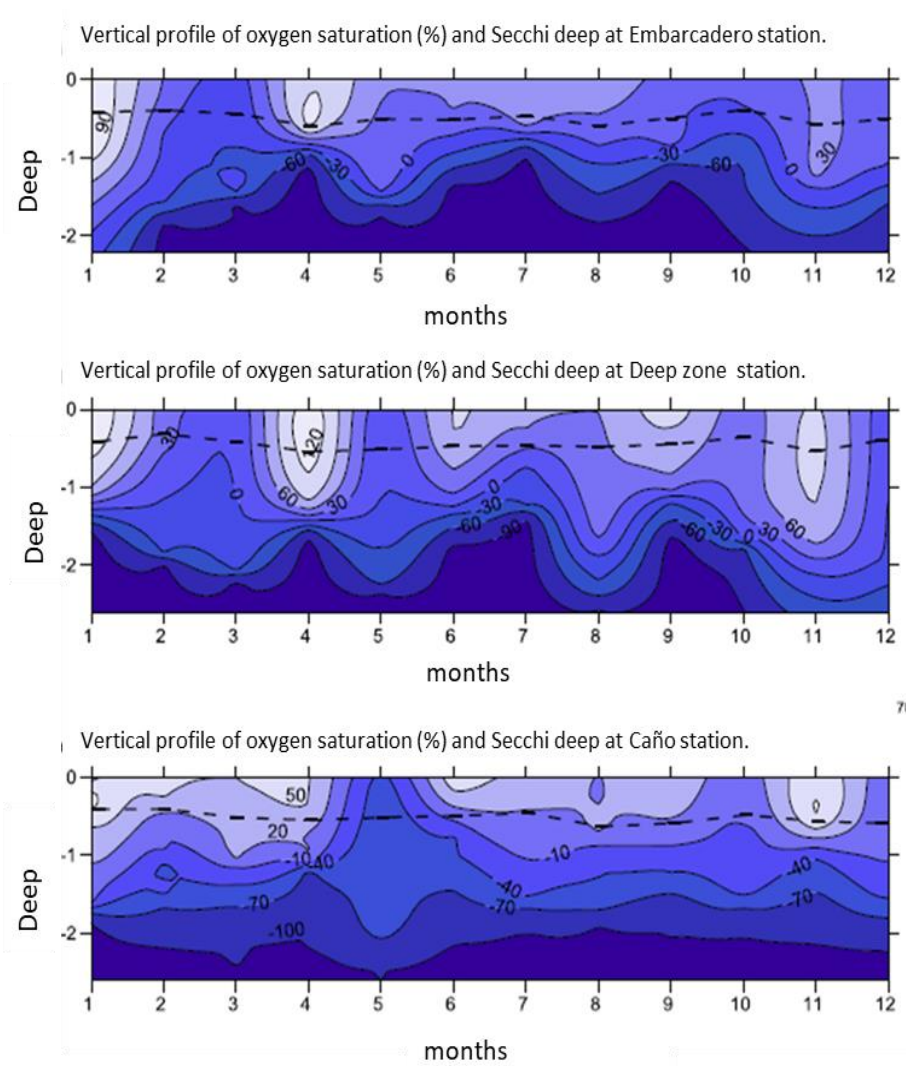

Figure 4. Secchi Deep and oxygen saturation in Limoncocha lagoon (Martín Hernández, 2015). The dashed line indicates the Secchi depth.

C. raciborskii is associated with low salinity conditions (Padisák, 1997) as such found in the Limoncocha lagoon, although it could also live with moderate salinity (Calandrino \& Paerl, 2011).

Regarding the nitrogen assimilation, some studies have shown $C$. raciborskii to have preference for ammonia (Spröber et al., 2003) which is present in the lagoon (Table 1). The absence of thricomes with two heterocysts (Figure 2.b) matches with the fact that the 
amount of heterocysts is inversely proportional to the inorganic nitrogen concentration in the media (Bouvyli et al., 1999; Briand et al., 2002).

C. raciborskii has a great autonomy regarding phosphorus needs for it is capable of assimilating and storing phosphorus easily (Wu et al., 2009; Isvanovics et al., 2000). Thus, low phosphorus concentration in the lagoon does benefit $C$. raciborskii over other organisms. Furthermore, Bar-Yosef et al. (2010) showed that lack of inorganic phosphorus leads the discharge of CYN hepatotoxin by Aphanizomenon strain causing the death of microorganisms and so, releasing inorganic phosphates.

The N:P ratio is low in the lagoon (Table 1), which favors $C$. raciborskii proliferation in eutrophic environments (Chislock et al., 2014).

In general, Limoncocha lagoon conditions are auspicious to $C$. raciborskii blooms, representing a potential risk for the communities living on the lagoon shore. The Table 2 shows the concentration of $C$. raciborskii in September and November. Concentrations above 100.000 cells $/ \mathrm{mL}$ are consider a risk for the population according to the World Health Organization (1998), as those found in Playayacu River mouth.

Table 2. C. raciborskii density (cel/mL) per month.

\begin{tabular}{lllll}
\hline Month & $\begin{array}{l}\text { Playayaku } \\
(\mathrm{B})\end{array}$ & $\begin{array}{l}\text { Pishira } \\
(\mathrm{C})\end{array}$ & $\begin{array}{l}\text { Caño } \\
(\mathrm{D})\end{array}$ & $\begin{array}{l}\text { Napo } \\
(\mathrm{F})\end{array}$ \\
\hline September & 128750 & 12500 & 8750 & 7500 \\
November & 135000 & 118750 & 98750 & 97500 \\
\hline
\end{tabular}

\subsection{Ocurrence of $C$. raciborskii in Ecuador}

Cylindrospermopsis raciborskii has been reported at river Daule basin, (-80,00766382550 -1,96826402406, $5 \mathrm{~m}$ altitude above sea level) (Prado M. \& Bucheli R., 2012); Yaguarcocha lagoon (-76,60000000000 -0,40000000000; $2.201 \mathrm{~m}$ above sea level) (Saelens, 2015) and Limoncocha Lagoon (-76,60000000000-0,40000000000; $244 \mathrm{~m}$ above sea level) (Figure 1).

Ecuador is located on either side of the equator and crossed by the Andes range with a maximum altitude of $6,268 \mathrm{~m}$ : the snowcap Chimborazo volcano. Thus, the highest biotopes in the world are found in this country, since the snow level stays at ca $5000 \mathrm{~m}$. Saelens reported which is so far the highest location record for C. raciborskii: the Yaguarcocha lagoon, 2,201m (Saelens, 2015) (Figure 1). We expect to find the cyanobacteria even at higher altitudes, where the temperature range matches that from the lake Constance, in Otawa, Canada, one of the coldest places where C. raciborskii has been reported (Hamilton et al., 2005).

\section{Acknowledgements}

Thanks to "Ministerio de Ambiente del Ecuador" for permission. To Jendry Moya and Jaqueline de Moya for the logistics and help at the biological station UISEK. To Juan Carlos Navarro for reviewing this paper.

Funds from the project "Eutrofización de los sistemas lóticos y lénticos de los andes y amazonía ecuatoriana y su implicación en la cadena trófica dulceacuícola" n P081617UISEK.

\section{References}

Antunes, J. T., Leão, P. N., \& Vasconcelos, V. M. (2015). Cylindrospermopsis raciborskii: review of the distribution, phylogeography, and ecophysiology of a global invasive species. Frontiers in Microbiology, 6, 473. http://doi.org/10.3389/fmicb.2015.00473 
Azevedo, S. M. F. O., Carmichael, W. W., Jochimsen, E. M., Rinehart, K. L., Lau, S., Shaw, G. R., \& Eaglesham, G. K. (n.d.). Human intoxication by microcystins during renal dialysis treatment in Caruaru*/ Brazil.

Berman-Frank, I., Lundgren, P., \& Falkowski, P. (2003). Nitrogen fixation and photosynthetic oxygen evolution in cyanobacteria. Research in Microbiology, 154, 157-164. http://doi.org/10.1016/S0923-2508(03)00029-9

Bonilla, S., Aubriot, L., Soares, M. C. S., González-Piana, M., Fabre, A., Huszar, V. L. M., Kruk, C. (2012). What drives the distribution of the bloom-forming cyanobacteria Planktothrix agardhii and Cylindrospermopsis raciborskii? FEMS Microbiology Ecology, 79(3), 594-607. http://doi.org/10.1111/j.1574-6941.2011.01242.x

Bouvyli, M., Molica2, R., De Oliveira3, S., Marinho3, M., \& Beker4, B. (1999). Dynamics of a toxic cyanobacterial bloom (Cylindrospermopsis raciborskii) in a shallow reservoir in the semi-arid region of northeast Brazil, 20, 285-297.

Briand, J. ., Robillot, C., Quiblier-Llobéras, C., Humbert, J. ., Couté, A., \& Bernard, C. (2002). Environmental context of Cylindrospermopsis raciborskii (Cyanobacteria) blooms in a shallow pond in France. Water Research, 36(13), 3183-3192. http://doi.org/10.1016/S0043-1354(02)00016-7

Calandrino, E. S., \& Paerl, H. W. (2011). Determining the potential for the proliferation of the harmful cyanobacterium Cylindrospermopsis raciborskii in Currituck Sound, North Carolina. Harmful Algae, 11, 1-9. http://doi.org/10.1016/j.hal.2011.04.003

Chislock, M. F., Sharp, K. L., \& Wilson, A. E. (2014). Cylindrospermopsis raciborskii dominates under very low and high nitrogen-to-phosphorus ratios. Water Research, 49, 207-214. http://doi.org/10.1016/j.watres.2013.11.022

Durañona, G. D. G. (2005). Estudio de los sedimentos de la laguna de Limoncocha. Tesis de grado. Facultad de Ambientales, Universidad Internacional SEK, Quito, Ecuador

Hach. (n.d.). Manual de Análisis de Agua Segunda edición en español. Retrieved from file:///C:/Users/Karla Lavanda/Downloads/Water Analysis Manual-Spanish-Manual de Analisis de Agua.pdf

Hammer, Ø., Harper, D. A. T., RYAN, P. D. 2001. PAST: Paleontological Statistics Software Package for Education and Data Analysis. Palaeontologia Electronica, 4(1): 9p.

Hamilton, P. B., Ley, L. M., Dean, S., \& Pick, F. R. (2005). The occurrence of the cyanobacterium Cylindrospermopsis raciborskii in Constance Lake: an exotic cyanoprokaryote new to Canada. Phycologia, 44(1), 17-25.

Hawkins, P. R., Runnegar, M. T. C., Jackson, A. R. B., Falconer2, I. R., Jackson, R. B., Runnegar, M. T. C., ... Megarty, M. (1985). Severe Hepatotoxicity Caused by the Tropical Cyanobacterium (Blue-Green Alga) Cylindrospermopsis raciborskii (Woloszynska) Seenaya and Subba Raju Isolated from a Domestic Water Supply Reservoir. Applied and Environmental Microbiology, 50(5), 1292-1295.

Instituto Geográfico Militar. (2017). Base de datos cartográfica escala 1: 50.000.

Isvanovics, V., Shafik, H. M., Presing, M., \& Juhos, S. (2000). Growth and phosphate uptake kinetics of the cyanobacterium, Cylindrospermopsis raciborskii (Cyanophyceae) in throughflow cultures. Freshwater Biology, 43(2), 257-275. http://doi.org/10.1046/j.1365-2427.2000.00549.x

Ken-a-vision. (n.d.). Applied Vision 4 Software. Retrieved from http://ken-avision.com/support/applied-vision-4-software-2

Komárek, J. \& Komárková-Legnerová, J. (2003). Phenotype diversity of the cyanoprokaryotic genus Cylindrospermopsis (Nostocales). Czech Phycology, 3, 130.

Llamas, R \& Custodio, E. (1972). Diferencias significativas entre los aprovechamientos de aguas subterráneas y superficiales: aspectos fisicoquímicos. Internacionals, núm. 4546, pp. 35-57. 
Padisák, J. (1997). Cylindrospermopsis raciborskii (Woloszynska) Seenayya et Subba Raju, an expanding, highly adaptive cyanobacterium: worldwide distribution and review of its ecology.

Padisák, J., \& Reynolds, C. S. (1998). Selection of phytoplankton associations in Lake Balaton, Hungary, in response to eutrophication and restoration measures, with special reference to the cyanoprokaryotes. Hydrobiologia, 384(1/3), 41-53. http://doi.org/10.1023/A:1003255529403

Prado M. \& Bucheli R. (2012). Distribución y abundancia del plancton en el embalse Daule.Peripa durante 2011-2012. Guayaquil.

Saelens, P. (2015). Ecological functioning of a shallow lake in Ecuador, Laguna Yahuarcocha. K.U. Leuven, Kulak.

Schwaderer, A. S., Yoshiyama, K., de Tezanos Pinto, P., Swenson, N. G., Klausmeier, C. A., \& Litchman, E. (2011). Eco-evolutionary differences in light utilization traits and distributions of freshwater phytoplankton. Limnology and Oceanography, 56(2), 589598. http://doi.org/10.4319/lo.2011.56.2.0589

Smayda, T. (1997). What is a Blomm? Limnology and Oceanography, 42, 1132-1136.

Sprőber, P., Shafik, H. M., Présing, M., Kovács, A. W., \& Herodek, S. (2003). Nitrogen uptake and fixation in the cyanobacterium Cylindrospermopsis raciborskii under different nitrogen conditions. Hydrobiologia, 506-509(1-3), 169-174. http://doi.org/10.1023/B:HYDR.0000008617.90245.5f

Stüken, A., Rücker, J., Endrulat, T., Preussel, K., Hemm, M., Nixdorf, B., Wiedner, C. (2006). Distribution of three alien cyanobacterial species (Nostocales) in northeast Germany: Cylindrospermopsis raciborskii, Anabaena bergii and Aphanizomenon aphanizomenoides. Phycologia, 45(6), 696-703. http://doi.org/10.2216/05-58.1

World health Organization. (1999). Toxic Cyanobacteria in Water: A guide to their public health consequences, monitoring and management. (I. Chorus \& J. Bartram, Eds.)

Wu, Z., Shi, J., \& Li, R. (2009). Comparative studies on photosynthesis and phosphate metabolism of Cylindrospermopsis raciborskii with Microcystis aeruginosa and Aphanizomenon flos-aquae. Harmful Algae, 8(6), 910-915. http://doi.org/10.1016/j.hal.2009.05.002 